\title{
Microbial transformation of quinic acid to shikimic acid by Bacillus megaterium
}

\author{
Saptarshi Ghosh, Harish Pawar, Omkar Pai and Uttam Chand Banerjee*
}

\begin{abstract}
Background: Biotransformation of quinic acid to shikimic acid was attempted using whole cells of Bacillus megaterium as a biocatalyst.

Results: Physico-chemical parameters such as temperature $\left(37^{\circ} \mathrm{C}\right), \mathrm{pH}(7.0)$, agitation (200 rpm), substrate (5 mM) and cell mass concentrations $(200 \mathrm{~kg} / \mathrm{m} 3)$ and reaction time $(3 \mathrm{~h})$ were found optimum to enhance the bioconversion. Maximum conversion (89\%) of quinic acid to shikimic acid was achieved using the above optimized parameters. Shikimic acid was extracted from the reaction mixture by a $\mathrm{pH}$-dependent method and maximum recovery (76\%) was obtained with petroleum ether.
\end{abstract}

Conclusions: Biotransformation of quinic acid to shikimic acid seems to be a better alternative over its fermentative production.

Keywords: Shikimic acid; Quinic acid; Biotransformation

\section{Background}

Shikimic acid, a key intermediate of the aromatic amino acid synthesis pathway [1] has immense pharmaceutical importance. This pathway is present in animals, plants and even in microorganisms as the common route for the synthesis of aromatic compounds [2-4]. Shikimic acid, a highly functionalized six-membered carbocyclic ring with three asymmetric centres, is a potent chiral building block for the synthesis of several biologically important compounds [5]. Three aromatic amino acids, more than ten different antibiotics and many herbicides and pesticides have been synthesized from shikimic acid. The molecule has come under limelight in the recent years as it is an important precursor for the synthesis of Oseltamivir (Tamiflu), the only drug against avian flu caused by H5N1 virus [6,7]. Synthesis of Tamiflu is solely dependent on the supply of shikimic acid. It is estimated that nearly twothirds of the requirement of shikimic acid is still being sourced from plants, with the remaining one-third only obtained from genetically engineered Escherichia coli $[8,9]$. Several genetically modified strains have been used for over production of shikimic acid by fermentation,

\footnotetext{
* Correspondence: ucbanerjee@niper.ac.in

Department of Pharmaceutical Technology (Biotechnology), National Institute of Pharmaceutical Education and Research, Sector- 67, S.A.S. Nagar, Punjab 160062, India
}

based on alteration in the central carbon metabolism [10-15]. Still, there is a need to develop cost-effective and better alternative method for shikimic acid production. Microbial biotransformation has been used for the production of shikimic acid from quinic acid in recent few years as a potent alternative of the available methods $[16,17]$. The production of shikimic acid from quinic acid (1.4 $\mathrm{mM})$ using Gluconobacter oxydans as biocatalyst has been reported $[18,19]$ with both whole cell catalyst and immobilized cell system (57\% to $77 \%$ bioconversion). In the biotransformation, quinate dehydrogenase (QDH), a classical membrane-bound quinoprotein containing pyrroloquinoline quinine (PQQ) as the coenzyme functions as the primary enzyme in quinate oxidation converting quinic acid to 3-dehydroquinate (3-DHQ) (Figure 1) [9,18]. This 3-DHQ further gets converted to 3dehydroshikimate (3-DHS) by 3-dehydroquinate dehydratase (DQD). Finally, 3-DHS gets converted to shikimic acid by the action of nicotinamide adenine dinucleotide phosphate (NADP)-dependent shikimate dehydrogenase (SKDH). Entry into the shikimate pathway from quinic acid seems to be advantageous over the classical pathway starting from glucose as there is less number of steps involved. From quinic acid, it is converted to shikimate by three enzymatic steps using microbial biotransformation [19]. Bioconversion of dehydroshikimate $(0.2 \mathrm{mM})$ to

\section{Springer}




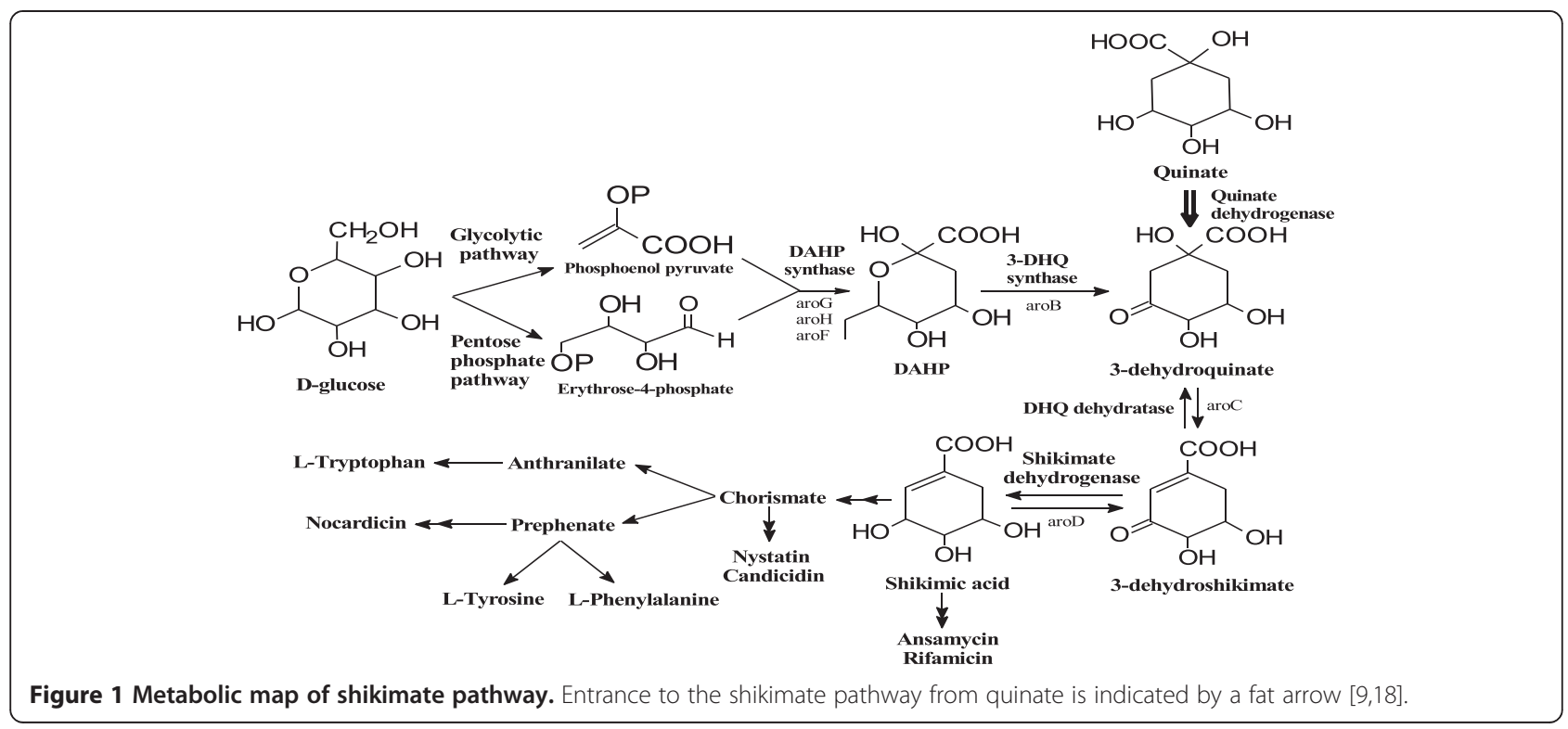

shikimate using purified shikimate dehydrogenase with $100 \%$ yield was also reported in literature [20]. In this study, whole cells of Bacillus megaterium MTCC 428 were used as biocatalyst for the transformation of quinic acid to shikimic acid. Various physico-chemical parameters of the biochemical reaction were optimized to enhance the yield of shikimic acid.

\section{Material and methods Materials}

Quinic acid, shikimic acid and dehydroshikimic acid were obtained from Sigma Aldrich chemical company (Milawukee, WI, USA). Growth media components were purchased from Hi-Media Inc. (Mumbai, India). All other chemicals were of analytical grade.

\section{Microorganisms and culture conditions}

Bacillus megaterium MTCC 428 was obtained from Microbial Type Culture Collection, Institute of Microbial Technology, Chandigarh, India. The organism was cultured at $37^{\circ} \mathrm{C}$ in modified nutrient broth (NB) medium ( $\mathrm{pH} 7.0)$ for $24 \mathrm{~h}$. The media components were as follows $\left(\mathrm{kg} / \mathrm{m}^{3}\right)$ : peptone 10 , beef extract 1.5 , yeast extract 1.5 , and glucose 10 .

\section{Biocatalyst preparation}

The strain was revived from glycerol stock and grown in a $20 \mathrm{~mL}$ medium and transferred $(5 \%, v / v)$ to $100 \mathrm{~mL}$ production medium at $37^{\circ} \mathrm{C}(200 \mathrm{rpm})$ in an incubator shaker (Kuhner shaker, Germany). After $24 \mathrm{~h}$, cells were harvested by centrifugation at 10,000 $\times g$ (Sigma 6 K15, $\mathrm{GmbH}$, Germany). Cells were thoroughly washed with $100 \mathrm{mM}$ phosphate buffer ( $\mathrm{pH}$ 7.0), and resuspended in the same buffer with a cell concentration of $100 \mathrm{~kg} / \mathrm{m}^{3}$ and used for the biotransformation reaction.

\section{Optimization of biotransformation parameters}

Various physico-chemical parameters for the biotransformation of quinic acid to shikimic acid were optimized in $5 \mathrm{~mL}$ reaction mixture by varying one parameter at a time. Temperature was varied between $25^{\circ} \mathrm{C}$ to $45^{\circ} \mathrm{C}$ and $\mathrm{pH}$ values were adjusted between $\mathrm{pH} 4.0$ to 9.0. An increased substrate concentration (2 to $20 \mathrm{mM}$ ) in the reaction mixture was used. The cell mass concentration was varied between 100 to $400 \mathrm{~kg} / \mathrm{m}^{3}$. To optimize the cofactor recycling, different glucose concentrations $(0.05$ to $0.4 \mathrm{M}$ ) were used in the reaction mixture. The effect of reaction time on the yield of shikimic acid was observed by carrying out the reaction up to $6 \mathrm{~h}$.

\section{Analytical methods}

\section{High-performance liquid chromatography}

An analytical HPLC method was developed using highperformance liquid chromatography system (Shimadzu 10 AD VP, Kyoto, Japan). Shikimic acid was analyzed on an Alltech OA-2000 organic acid column $(100 \times 6.5 \mathrm{~mm}$, $6.5 \mu \mathrm{m})$ (Grace Davison Discovery Science, Deerfield, IL, USA) using $2.5 \mathrm{mM} \mathrm{H}_{2} \mathrm{SO}_{4}$ as mobile phase at a flow rate of $0.3 \mathrm{~mL} / \mathrm{min}$ and detected at $215 \mathrm{~nm}$ by UV detector. A standard curve of shikimic acid was made to quantify the biotransformation.

\section{LC-MS analysis}

Reaction mixture was analyzed by LC-MS (Model: LTQ$\mathrm{XL}$, Thermo Scientific, USA) to further confirm the product formation. Alltech OA-2000 organic acid column $(100 \times 6.5 \mathrm{~mm}, 6.5 \mu \mathrm{m})$ (Grace Davison Discovery 
Science, Deerfield, IL, USA) was used with $5 \mathrm{mM}$ formic acid as mobile phase at a flow rate of $0.5 \mathrm{~mL} / \mathrm{min}$ and detected by UV detector at $215 \mathrm{~nm}$.

\section{MALDI-TOF analysis}

Samples were analyzed in MALDI-TOF/TOF mass spectrometer (Bruker Ultraflex-TOF/TOF, Madison, WI, USA) for detecting the molecular mass of the product. After the reaction, sample was extracted by petroleum ether with $\mathrm{pH}$ adjustment and dried under vacuum. The dried sample was solubilized in methanol and used for the analysis.

\section{NMR analysis}

After the completion of the reaction, the mixture was extracted with petroleum ether by $\mathrm{pH}$ adjustment and dried under vacuum. The dried sample was solubilized in DMSO and ${ }^{1} \mathrm{H}$ NMR and ${ }^{13} \mathrm{C}$ NMR spectra were obtained with Bruker AVANCE $400 \mathrm{MHz}\left({ }^{1} \mathrm{H} 400\right.$ and ${ }^{13} \mathrm{C}$ $100 \mathrm{MHz}$ ). Chemical shifts were expressed in $\delta$ units relative to the tetramethylsilane (TMS) signal as an internal reference in DMSO.

\section{Extraction of shikimic acid from reaction mixture}

Being a highly polar compound, it is very hard to isolate shikimic acid from the reaction mixture by solvent extraction. Therefore, pH-dependent extraction method was selected where, at a particular $\mathrm{pH}$, the compound gets deionized and it comes into the organic non-polar phase during solvent extraction. Before the extraction, the $\mathrm{pH}$ of the solution was adjusted to 4.48 and extracted with different solvents such as ethyl acetate, dichloromethane, $n$-butanol, petroleum ether, etc.

\section{Results and discussion}

\section{Biotransformation of quinic acid to shikimic acid using} whole cells of $B$. megaterium

Quinic acid is converted to shikimic acid by two enzymatic systems in Gluconobacter oxydans, as reported by Adachi et al. $[19,20]$. Along with the classical shikimate pathway, starting from glucose, quinic acid can also be a potential entry point with the formation of 3-dehydroquinate by the enzyme quinate dehydrogenase. The reaction was carried out with quinic acid as the substrate and whole cells of $B$. megaterium as the catalyst. The reaction conditions were as follows: quinic acid, $2.5 \mathrm{mM}$; cell mass concentration, $100 \mathrm{~kg} / \mathrm{m}^{3}$; temperature, $30^{\circ} \mathrm{C}$; mixing rate $200 \mathrm{rpm}$. Under the un-optimized conditions $42 \%$ conversion of quinic acid to shikimic acid was obtained (Additional file 1: Figure 1-4 of Supporting Information).

\section{Optimization parameters}

Various physico-chemical parameters for the biotransformation of quinic acid to shikimic acid using whole cells of $B$. megaterium were optimized.



Figure 2 Effect of reaction time on transformation of quinic acid to shikimic acid by whole cells of $B$. megaterium.

\section{Effect of reaction time}

To determine the effect of reaction time, the reaction mixture $(5 \mathrm{~mL})$ containing whole cells of $B$. megaterium $\left(200 \mathrm{~kg} / \mathrm{m}^{3}\right)$, quinic acid $(5 \mathrm{mM})$, and glucose $(5 \%)$ was incubated at $30^{\circ} \mathrm{C}(200 \mathrm{rpm})$. Samples were taken at $1 \mathrm{~h}$ interval upto $6 \mathrm{~h}$. It is evident from Figure 2 that maximum conversion took place in $3 \mathrm{~h}$ while it decreased with the incubation time (Additional file 1: Figure 5 of Supporting Information). It might be due to the oxidation of shikimic acid to dehydroshikimate on long incubation. Hence, the subsequent experiments were carried out for $3 \mathrm{~h}$ only which is better than the previous reports of having $1.5 \mathrm{~h}$ as reaction time with $1.4 \mathrm{mM}$ substrate [19] and $5 \mathrm{~h}$ as reaction time with $0.2 \mathrm{mM}$ substrate [20].

\section{Effect of reaction temperature}

To investigate the effect of reaction temperature, the reaction mixtures as mentioned above were incubated at various temperatures $\left(20^{\circ} \mathrm{C}\right.$ to $\left.45^{\circ} \mathrm{C}\right)$. It is evident from Figure 3 that percentage conversion increased with the increase of incubation temperature and maximum




conversion was obtained at $37^{\circ} \mathrm{C}$ (Additional file 1: Figure 6 of Supporting Information). At higher temperature $\left(45^{\circ} \mathrm{C}\right)$, the percentage conversion decreased. It might be due to the deactivation of the enzyme at higher temperature or oxidation of shikimic acid to dehydroshikimate by the reverse reaction. Biotransformation of quinic acid to shikimic acid by whole cells and pure enzyme was also reported in literature and in both the cases the reactions were carried out at $25^{\circ} \mathrm{C}[19,20]$.

\section{Effect of reaction $\mathrm{pH}$}

To determine the effect of reaction $\mathrm{pH}$, the reaction mixtures as mentioned above were incubated at $37^{\circ} \mathrm{C}$ having different initial $\mathrm{pHs}$. The initial $\mathrm{pHs}$ of the reaction mixtures were adjusted between 4.0 to 9.0 using various buffers. It is evident from Figure 4 that percentage conversion increased with the increase in $\mathrm{pH}$ and maximum conversion was obtained at $\mathrm{pH} 7.0$ which was similar to the previous reports $[19,20]$ (Additional file 1: Figure 7 of Supporting Information). It was seen that at higher $\mathrm{pH}$ (7.5 to 9.0) there was a decrease in percentage conversion. It might be due to the oxidation of shikimic acid to dehydroshikimate by reverse reaction.

\section{Effect of substrate concentration}

To determine the effect of substrate concentration, reactions were carried out with the increasing concentrations of quinic acid ( 2 to $20 \mathrm{mM}$ ). It is evident from Figure 5 that maximum conversion took place with $5 \mathrm{mM}$ quinic acid and it decreased with the increasing substrate concentration (Additional file 1: Figure 8 of Supporting Information). The low conversion of quinic acid to shikimic acid at higher substrate concentration might be due to the substrate inhibition. In our case, biotransformation with the whole cells of $B$. megaterium, a maximum of $80 \%$ conversion with $5 \mathrm{mM}$ quinic acid was obtained while $55 \%$ to $77 \%$ conversion with the whole cells of Gluconobacter oxydans with $1.4 \mathrm{mM}$ substrate was reported by Adachi et al.

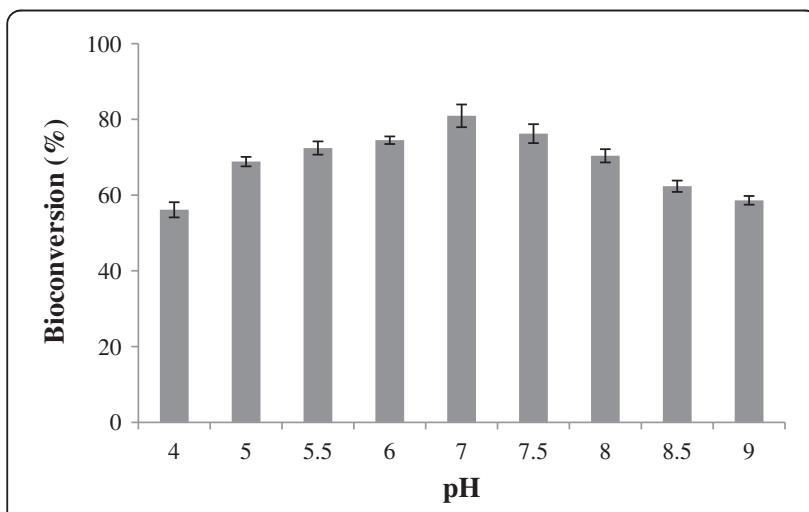

Figure 4 Effect of $\mathrm{pH}$ on transformation of quinic acid to shikimic acid by whole cells of $B$. megaterium.

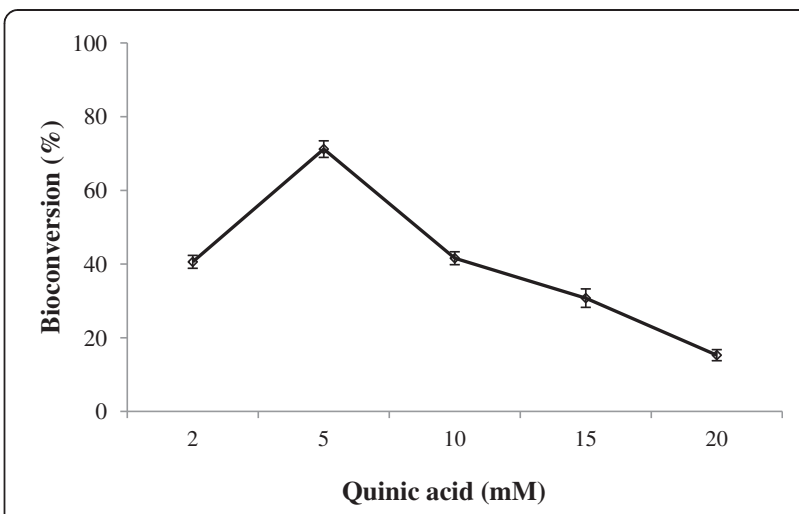

Figure 5 Effect of substrate concentration on transformation of quinic acid to shikimic acid by whole cells of $B$. megaterium.

[19]. At higher substrate concentration (above $5 \mathrm{mM}$ ), quinate dehydrogenase, the foremost enzyme in the biotransformation pathway might be inhibited.

\section{Effect of cell mass concentration}

To determine the effect of cell mass (biocatalyst) concentration, reactions were carried out with increasing cell mass concentrations $\left(100\right.$ to $\left.400 \mathrm{~kg} / \mathrm{m}^{3}\right)$. It is seen from Figure 6 that maximum conversion was achieved with a cell mass concentration of $200 \mathrm{~kg} / \mathrm{m}^{3}$ and decreased thereafter (Additional file 1: Figure 9 of Supporting Information). Higher viscosity of the reaction mixture at higher cell mass concentration might be responsible for the lower bioconversion. Here, $84 \%$ bioconversion was achieved with $200 \mathrm{~kg} / \mathrm{m}^{3}$ cell mass at $3 \mathrm{~h}$, while previous report mentioned a conversion of $57 \%$ to $77 \%$ at $20 \mathrm{~h}$ with $25 \mathrm{~kg} /$ $\mathrm{m}^{3}$ cell mass [19] (Additional file 1: Figure 11 of Supporting Information).

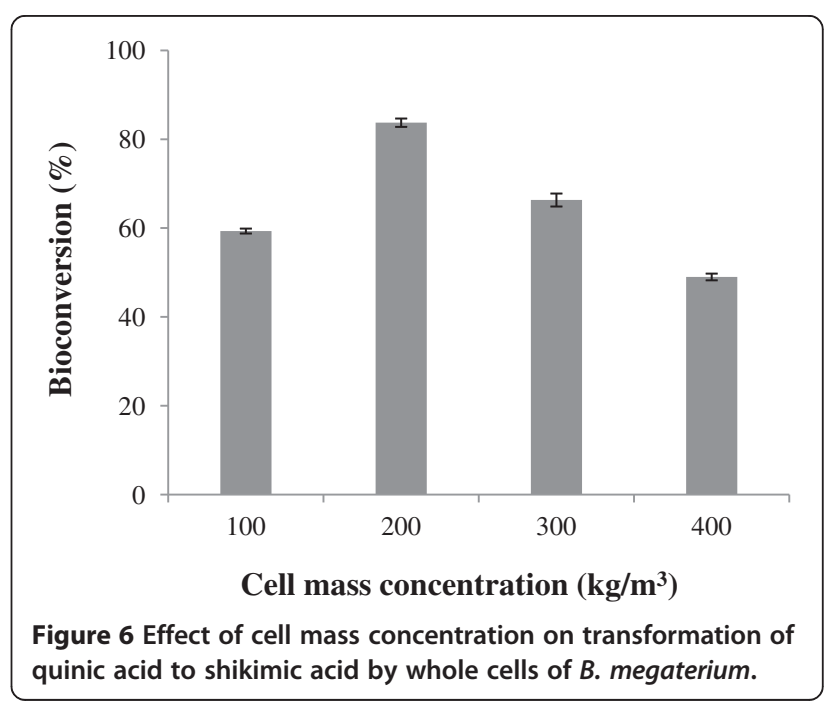




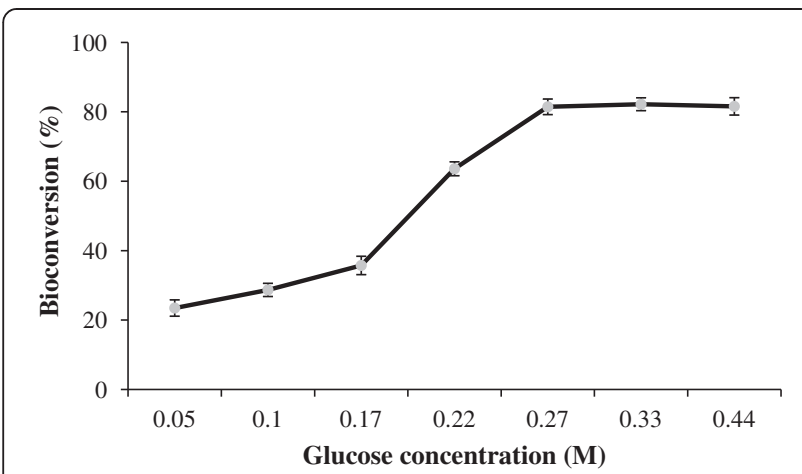

Figure 7 Effect of glucose concentration on transformation of quinic acid to shikimic acid by whole cells of $B$. megaterium.

\section{Effect of glucose concentration}

Cofactor recycling plays a key role in the NADPHdependent enzyme biocatalysis; therefore, it is necessary to optimize the reaction condition for proper cofactor recycling $[21,22]$. To study the effect of cofactor generation, different concentrations of glucose $(0.05$ to $0.4 \mathrm{M})$ were used in the reaction mixture. It is evident from Figure 7 that percentage conversion increased with increase in glucose concentration and maximum conversion (81\%) was achieved with $0.3 \mathrm{M}$ glucose (Additional file 1: Figure 10 of Supporting Information). The conversion remained more or less same with the further increase of glucose concentration in the reaction mixture. Under the optimized conditions $\left(37^{\circ} \mathrm{C}, 200 \mathrm{rpm}, \mathrm{pH} 7.0\right) 89 \%$ conversion was achieved at $3 \mathrm{~h}$ (Figure 8 ) while $57 \%$ to $77 \%$ conversion was reported using whole cells of Gluconobacter oxydans by Adachi et al. [19] (Additional file 1: Figure 11 of Supporting Information).

\section{Optimization of downstream processing of shikimic acid from reaction mixture}

The $\mathrm{pH}$-dependent method was selected for the extraction of shikimic acid from the reaction mixture. After workup, the $\mathrm{pH}$ of the reaction mixture was adjusted to

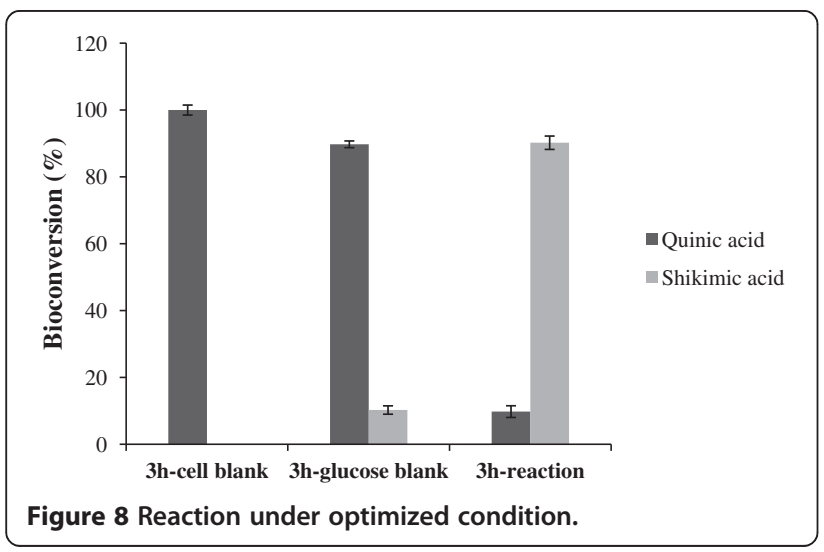

Table 1 Extraction of shikimic acid from reaction mixture using different solvents

\begin{tabular}{lccc}
\hline Number & Solvent & Amount recovered (mM) & Recovery (\%) \\
\hline 1 & Ethyl acetate & 1.15 & 25.55 \\
2 & Dichloromethane & 0.1 & 2.2 \\
3 & $n$-Butanol & 3.2 & 71.11 \\
4 & Petroleum ether & 3.42 & 76 \\
\hline
\end{tabular}

its $\mathrm{pKa}$ 4.48. Extraction was carried out using different solvents like ethyl acetate, $n$-butanol, petroleum ether and dichloromethane. Post extraction, the samples were concentrated on rotavapor and analyzed by HPLC. Maximum recovery (76\%) of shikimic acid was obtained with petroleum ether (Table 1). The sample was then analyzed by matrix-assisted laser desorption/ionisation (MALDI) and nuclear magnetic resonance (NMR).

\section{Identification of shikimic acid}

After the completion of the reaction, product was extracted by $\mathrm{pH}$-dependent method. The product was characterized as shikimic acid by ${ }^{1} \mathrm{H}$ and ${ }^{13} \mathrm{C}$ NMR and MALDI. Analytical data were as follows: ${ }^{1} \mathrm{H}$ NMR (400 MHz, MeOD): $\delta 2.18$ to 2.22 (days, $1 \mathrm{H}$ ), 2.69 to 2.73 (days, $1 \mathrm{H}$ ), 3.69 to 3.70 (days, $1 \mathrm{H}$ ), 4.01 (s, $1 \mathrm{H}$ ), 4.38 (s, 1H), $6.81(\mathrm{~s}, 1 \mathrm{H}) ;{ }^{13} \mathrm{C}$ NMR (100 MHz, MeOD): $\delta$ 31.69, 67.35, 68.41, 72.78, 130.82, 138.81, 170.20; MALDI-TOF-TOF: $m / z$ 197.32, 213.32 (Additional file 1: Figure 12-16 of Supporting Information).

\section{Conclusion}

A potential biotransformation process is reported for the production of shikimic acid using whole cells of $B$. megaterium as biocatalyst. Various reaction parameters (reaction time, temperature, $\mathrm{pH}$, substrate, biocatalyst concentration, etc.) were optimized. Maximum conversion (89\%) was achieved under the optimized condition. Biotransformation of quinic acid to shikimic acid using purified enzymes are also reported; however, it has many limitations such as the use of co-factors (NADH/NAD ${ }^{+}$) in the reaction mixture and the quick denaturation of the enzyme during the course of reaction. Although a major advantage of mass transfer limitations are omitted in a cell-free system, due to inherent problems of enzyme denaturation, which makes this method difficult. The main limitation of transformation of quinic acid to shikimic acid is the use of higher substrate concentration. The enzyme titre may be increased by the welldeveloped techniques of recombinant DNA technology, directed evolution, etc. Shikimic acid production from quinate seems to be a better alternative over its fermentative production. 


\section{Additional file}

Additional file 1: Supporting information.

\section{Abbreviations}

DAHP: 3-deoxy-arabino-heptulosonate-7-phosphate; DHQ: 3-dehydroquinate; DHS: 3-dehydroshikimate; DQD: 3-dehydroquinate dehydratase; GDH: glucose dehydrogenase; HPLC: high-performance liquid chromatography; MALDI: matrix assisted laser desorption/ionisation; MTCC: microbial type culture collection; NADP: nicotinamide adenine dinucleotide phosphate; NADPH: reduced form of nicotinamide adenine dinucleotide phosphate; NMR: nuclear magnetic resonance; QDH: quinate dehydrogenase; rpm: revolutions per minute; SKDH: Shikimate dehydrogenase.

\section{Competing interests}

The authors declare that they have no competing interests.

\section{Authors' contributions}

SG carried out experiments and data analysis during the study and drafted the manuscript. HP participated in the design of the study and performed experiments. OP conceived of the study and participated in designing experiments. UCB has been involved in drafting the manuscript and revising it critically for important intellectual content and also given final approval of the version to be published. All authors read and approved the final manuscript.

\section{Acknowledgement}

One of the authors SG acknowledges the financial support by Indian Council of Medical Research, India.

Received: 17 April 2014 Revised: 26 June 2014

Accepted: 27 June 2014

\section{References}

1. Herrmann KM, Weaver LM (1999) The shikimate pathway. Annu Rev Plant Physiol Plant Mol Biol 50:473-503

2. Ganem B (1978) Shikimate-derived metabolites: from glucose to aromatics recent developments in natural-products of shikimic acid pathway. Tetrahedron 34:3353-3383

3. Pittard AJ (1996) Biosynthesis of aromatic amino acids. In: Neidhardt FC, Curtiss R III, Ingraham JL, Lin ECC, Low KB, Magasanic B, Reznikoff WS, Riley M, Schaechter M, Umbarger HE (eds) Escherichia coli and Salmonella. Cellular and Molecular Biology. American Society of Microbiology, Washington, DC, pp 458-484

4. Herrmann KM (1995) The shikimate pathway: early steps in the biosynthesis of aromatic compounds. Plant Cell 7:907-919

5. Krämer M, Bongaerts J, Bovenberg R, Kremer S, Müller U, Orf S, Wubbolts M, Raeven $L$ (2003) Metabolic engineering for microbial production of shikimic acid. Metab Eng 5:277-283

6. Farina V, Brown JD (2006) Tamiflu: the supply problem. Angew Chem Int Ed 45:7330-7334

7. Raghavendra TR, Vaidyanathan P, Swathi HK, Ramesha BT, Ravikanth G, Ganeshaiah KN, Srikrishna A, Shaanker RU (2009) Prospecting for alternate sources of shikimic acid, a precursor of Tamiflu, a bird-flu drug. Curr Sci 96(6):771-772

8. Payne R, Edmonds M (2005) Isolation of shikimic acid from star anise seeds. J Chem Educ 82:599-600

9. Ghosh S, Chisti Y, Banerjee UC (2012) Production of shikimic acid. Biotechnol Adv 30:1425-1431

10. Knop DR, Draths KM, Chandran SS, Barker JL, Frost JW (2001) Hydroaromatic equilibrium during biosynthesis of shikimic acid. J Am Chem Soc 123:10173-10182

11. Chandran SS, Yi J, Draths KM, Von Daeniken R, Weber W, Frost JW (2003) Phosphoenolpyruvate availability and the biosynthesis of shikimic acid. Biotechnol Prog 19:808-814

12. Johansson L, Lindskog A, Silfversparre G, Cimander C, Nielsen KF, Lidén G (2005) Shikimic acid production by a modified strain of E. coli (W3110.shik1) under phosphate-limited and carbon-limited conditions. Biotechnol Bioeng 92:541-552
13. Ahn JO, Lee HW, Saha R, Park MS, Jung JK, Lee DY (2008) Exploring the effects of carbon sources on the metabolic capacity for shikimic acid production in Escherichia coli using in silico metabolic predictions. J Microbiol Biotechnol 18:1773-1784

14. Escalante A, Calderón R, Valdivia A, de Anda R, Hernández G, Ramírez OT, Gosset G, Bolívar F (2010) Metabolic engineering for the production of shikimic acid in an evolved Escherichia coli strain lacking the phosphoenolpyruvate: carbohydrate phosphotransferase system. Microb Cell Fact 9:21

15. Cui YY, Ling C, Zhang YY, Huang J, Liu JZ (2014) Production of shikimic acid from Escherichia coli through chemically inducible chromosomal evolution and cofactor metabolic engineering. Microb Cell Fact 13:21

16. Mitsuhashi S, Davis BD (1954) Aromatic biosynthesis. XIII. Conversion of quinic acid to 5-dehydroquinic acid by quinic dehydrogenase. Biochim Biophys Acta 15:268-281

17. Yaniv H, Gilvarg C (1955) Aromatic biosynthesis. XIV. 5-dehydroshikimic reductase. J Biol Chem 213:787-795

18. Adachi O, Tanasupawat S, Yoshihara N, Toyama H, Matsushita M (2003) 3-Dehydroquinate production by oxidative fermentation and further conversion of 3-dehydroquinate to the intermediates in the shikimate pathway. Biosci Biotechnol Biochem 67:2124-2131

19. Adachi O, Ano Y, Toyama H, Matsushita K (2006) High shikimate production from quinate with two enzymatic systems of acetic acid bacteria. Biosci Biotechnol Biochem 70:2579-2582

20. Adachi O, Ano Y, Toyama H, Matsushita K (2006) Purification and properties of NADP-dependent shikimate dehydrogenase from Gluconobacter oxydans IFO 3244 and its application to enzymatic shikimate production. Biosci Biotechnol Biochem 70:2786-2789

21. Zhang J, Witholt B, Li Z (2006) Efficient NADPH recycling in enantioselective bioreduction of a ketone with permeabilized cells of a microorganism containing a ketoreductase and a glucose 6-phosphate dehydrogenase. Adv Synth Catal 348:429-433

22. Zhang W, O'Connor K, Wang DIC, Li Z (2009) Bioreduction with efficient recycling of NADPH by coupled permeabilized microorganisms. Appl Environ Microbiol 75(3):687-694

doi:10.1186/s40643-014-0007-7

Cite this article as: Ghosh et al:: Microbial transformation of quinic acid to shikimic acid by Bacillus megaterium. Bioresources and Bioprocessing 2014 1:7.

\section{Submit your manuscript to a SpringerOpen ${ }^{\circ}$ journal and benefit from:}

- Convenient online submission

$\checkmark$ Rigorous peer review

- Immediate publication on acceptance

- Open access: articles freely available online

- High visibility within the field

- Retaining the copyright to your article

Submit your next manuscript at springeropen.com 